\title{
Is Artificial Light at Night Dangerous for the Balkan Strict Protected Areas at Present?
}

\author{
Mykyta Peregrym $(\mathbb{D} \cdot$ Eva Kabaš $(\mathbb{D} \cdot$ \\ Alexander Tashev (D) - Snežana Dragićević (D) \\ Erika Pénzesné Kónya • Mariia Savchenko
}

Received: 4 November 2019 / Accepted: 31 January 2020 / Published online: 16 February 2020

(C) The Author(s) 2020

\begin{abstract}
The Balkan Peninsula has rich biodiversity with a large number of endemic species; therefore, a part of its territory has been recognized as a World Biodiversity Hotspot. Despite nature conservation efforts and development of nature conservation networks in countries of the region, anthropogenic influence on natural and semi natural ecosystems is increasing. Moreover, new types of disturbance and pollution arise, and one of the more recent being artificial light at night (ALAN) which has serious consequences on reproduction, navigation, foraging, habitat selection, communication, trophic and social interactions of the biota. We have estimated the level of ecological light pollution in the strict
\end{abstract}

M. Peregrym $(\bowtie) \cdot$ E. Pénzesné Kónya

Eszterházy Károly University, Leanyka Str., 6-8, Eger 3300,

Hungary

e-mail: mykyta.peregrym@uni-eszterhazy.hu

E. Kabaš

Faculty of Biology, Institute of Botany and Botanical Garden Jevremovac, University of Belgrade, Takovska 43,

Belgrade 11000, Serbia

\section{A. Tashev}

University of Forestry, Kliment Ohridsky Blvd., 10, 1797 Sofia, Bulgaria

\section{S. Dragićević}

Natural History Museum of Montenegro, Trg Vojvode Bećir bega Osmanagića 16, 81000 Podgorica, Montenegro

\section{Savchenko}

I.I. Schmalhausen Institute of Zoology of the National Academy of Sciences of Ukraine, Bohdan Khmelnytsky, Str., 15, Kyiv 01030, Ukraine protected areas of the Republic of Serbia, the Republic of Bulgaria, and Montenegro using available Google Earth Pro tools, and the New World Atlas of Artificial Sky Brightness (2016) in the form of a kmz layer. The research has covered 13 National Parks, 11 Nature Parks and 55 Reserves. Our results showed widespread incursion of ALAN within strict protected areas in the studied region that has also been noted for some other countries and regions too. However, the level of light pollution is lower here, than in the most part of Continental Europe, and there are a few areas in each country where the night sky above National and Natural Parks is almost dark. These territories have a special value for nature conservation; therefore, it is important to save the dark night sky there.

Keywords Artificial light at night (ALAN) - Ecological light pollution · Nature conservation · Protected areas . Balkans

The Balkan Peninsula has rich biodiversity with a large number of endemic species (Griffiths and Kryštufek 2004; Petrova and Vladimirov 2010; Tomović et al. 2014; Vuksanović et al. 2016). That is why a part of its territory in borders of Mediterranean has been recognized as a World Biodiversity Hotspot (Mittermeier et al. 1999, 2005; Myers et al. 2000). There are 6 biogeographic regions located within the Balkans: Alpine, Black Sea, Continental, Mediterranean, Pannonian, and Steppic (European Commission 2019; European Environment Agency 2012). Despite nature conservation efforts and development of nature 
conservation networks like the Important Bird Area Network (Puzovič 2009; Velevski et al. 2010), the Important Plant Area Network (Angelova et al. 2012; Melovski et al. 2012; Nikolić 2009; Petrović 2009; Stevanović and Šinžar-Sekulić 2009), the NATURA 2000 Network (Gussev and Tzonev 2015; The Ministry of Environment and Water of Bulgaria 2014), and Emerald Network (Convention on the Conservation of European Wildlife and Natural Habitats 2008; Group of Experts for the setting up of the Emerald Network of Areas of Special Conservation Interest 2003, 2006; Prokić 2008) in countries of the region, anthropogenic influence to natural and semi natural ecosystems has been increasing for a long time (Griffiths and Kryštufek 2004; Kulakowski et al. 2017; Longman et al. 2018; Marinova et al. 2012; The European Environment Agency 2011). Moreover, new types of disturbance and pollution arise, one of the more recent pressures is artificial light at night (ALAN) that has already been noted for protected areas of autonomous province of Vojvodina in North Serbia (Bjelajac and Đerčan 2019).

Nowadays there is no exact data about the level of ALAN from which the impact on biodiversity starts (Falchi et al. 2016), but a lot of evidence about ALAN influence on reproduction, navigation, foraging, habitat selection, communication, trophic, and social interactions of the biota have already been discussed (Bennie et al. 2016; Dominoni et al. 2016; Gaston and Bennie 2014; Hölker et al. 2010b; Longcore and Rich 2004; Navara and Nelson 2007; Rich and Longcore 2006). For example, ALAN has been documented as a contributing factor to the global decline in insect populations (Grubisic et al. 2018; Hallmann et al. 2017; Leather 2018; Macgregor et al. 2015). Furthermore, ecological light pollution not only can cause cascading effects in ecosystems, restructuring ecological communities by modifying the interactions between species, and impacting pollination and seed dispersal (Bennie et al. 2015a), but also being a driver of evolution across urban-rural landscapes (Hopkins et al. 2018). Unfortunately, understanding of benefits which human society has from ALAN (Boyce 2019; Gaston et al. 2015b), as well as its dynamics (Cinzano et al. 2001; Falchi et al. 2016, 2019; Kyba et al. 2017) does not allow considering this disturbance factor as temporary or insignificant for species, especially nocturnal ones.

In this case, strict protected areas have a special value for biodiversity conservation because the impact of different anthropogenic factors is minimized there. It must concern ALAN too; however, it is not taken into account by either scientists or authority in the majority of countries. There are only few countries like Italy, which enforce laws against light pollution (Falchi 2018). Though the investigations of the level of ecological light pollution within protected areas of some countries and regions show its widespread incursion (Bjelajac and Đerčan 2019; Gaston et al. 2015a; Guetté et al. 2018; Jiang et al. 2017; Peregrym et al. 2018). Therefore, in view of the foregoing, it has been decided to estimate the level of ecological light pollution and its danger for strict protected areas (Nature Reserves, National and Nature Parks) of the Balkans as unique places for biodiversity conservation.

\section{Material and Methods}

The research covers strict protected areas of three Balkan countries: the Republic of Serbia, the Republic of Bulgaria, and Montenegro. The Republic of Serbia is considered together with Kosovo region because the Republic of Kosovo is a partially recognized state and disputed territory still, though the nature management of Šar planina National Park which is located in this region is carried out by Kosovo government at present. These three countries have been selected because of their different political and economic status that is important in the context of the dependence of the level of ecological light pollution from economic development (Bennie et al. 2015b) and proceeding from data availability. GIS layers showing the borders of strict protected areas for Serbia were computed via site Geosrbija (https://a3. geosrbija.rs) on the basis of Map of Protected areas of

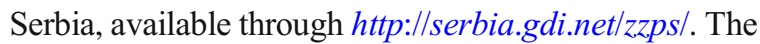
data for strict protected areas of Bulgaria was uploaded from the website of the Executive Environment Agency, the Ministry of Environment and Water of the Republic of Bulgaria (http://eea.government.bg/zpo/bg/index download.jsp). GIS layers with borders of Montenegrin National Parks were received by personal communication with these organizations; however, it is available schematically via https://nparkovi.me/mapaparkoval

The objects of our study were 13 National Parks, 11 Nature Parks and 55 Reserves: 5 National Parks (Đerdap, Fruška Gora, Kopaonik, Šar Planina, Tara) and 29 Nature Reserves (Bagremara, Carska bara, 
Deliblatska peščara, Goč-Gvozdac, Gornje Podunavlje, Jelašnička klisura, Jerma, Karađorđevo, Klisura reke Mileševke, Klisura reke Trešnjice, KoviljskoPetrovaradniski Rit, Kraljevac, Kukavica, Ludaško jezero, Mala jasenova glava, Obedska bara, Okanj bara, Paljevine, Pašnjaci velike droplje, Peštersko polje, Ritovi Donjeg Potisja, Selevenjske pustare, Slano Kopovo, Suva planina, Tesne jaruge, Titelski breg, Uvac, Venerina padina, Zasavica) in Serbia; 3 National Parks (Central Balkan, Pirin, Rila), 11 Nature Parks (Belasitsa, Bulgarka, Golden Sands, Persina, Rila Monastery, Rusenski Lom, Shumen Plateau, Sinite Kamani, Strandzha, Vitosha, Vrachanski Balkan), and 26 Nature Reserves (Ali Botush, Beglika, Beli Lom, Byala Krava, Chervanata Stena, Chuprene, Dupkata, Elenova Gora, Gorna Topchiya, Gornata Koria, Kaliakra, Kamenshchitza, Kastrakliy, Kamchia, Kazanite, Kupena, Leshnitsa, Mantaritza, Orelyak, Orlitzata, Ropotamo, Sokolata, Soskovcheto, Tisata, Tserna Reka, Velchi Dol) in Bulgaria; 5 National Parks (Biogradska gora, Durmitor, Lovćen, Prokletije, Skadarsko jezero) in Montenegro (Fig. 1). It is worth noting that there are 55 Nature Reserves in Bulgaria, but 29 of them are located within borders of National or Nature Parks, ; therefore, these territories have not been considered separately to avoid duplicating the results. Calculated data for these 29 areas are included in data for National and Nature Parks in a whole.

According to accepted biogeographic zoning (European Commission 2019; European Environment Agency 2012), they are located in the next way: 7 National Parks, 4 Nature Parks, and 15 Nature Reserves in Alpine region; 2 Nature Parks and 3 Nature Reserves in Black Sea region; 3 National Parks, 5 Nature Parks, and 21 Nature Reserves in Continental region; $2 \mathrm{Na}-$ tional Parks in Mediterranean region; 1 National Park and 16 Nature Reserves in Pannonian region (Fig. 1).

The study has been carried out using available tools from Google Earth Pro (version 7.3.2.5776; https://www.google.com/earth/). We used the New World Atlas of Artificial Sky Brightness in the form of a $\mathrm{kmz}$ (Keyhole Markup language Zipped) layer which was created by Falchi et al. (2016) and is available through its 3D Globe version (https://cires.colorado.edu/Artificial-light). We overlaid the GIS layers of the borders of the protected areas with the artificial sky brightness layer and counted the number of squares of each index of level of artificial sky brightness according to the legend of the atlas (Falchi et al. 2016).

\section{Results and Discussion}

The results of area calculations of different levels of artificial sky brightness within protected territories are presented in Table 1 for Serbia, in Table 2 for Bulgaria, and in Table 3 for Montenegro. Total results for different types of protected areas of three countries have been summarized in Table 4, as well as total results for different biogeographic regions are given in Table 5 . To quantify an error within the calculations, we have added two columns to each table, one column with the calculated area, and the other one with the official area (according to information from the Institute for Nature Conservation of Serbia (Brusin 2018), the Ministry of Environment and Water of Bulgaria (https://www.moew. government.bg/bg/priroda/zastiteni-teritorii/obstainformaciya-za-zastitenite-teritorii/), and the Public Enterprise for National Parks of Montenegro (http://nparkovi.me/dokumenti/) for every protected area). The highlighted discrepancy is generally not more than 3-5\% for studied territories in Bulgaria and Montenegro, except a few mountain ones like Rila Monastery Nature Park (7.83\%). The common situation with results of ecological light pollution levels calculations for Serbian protected areas is the same, but there are several ones (Paljevine, Tesne jaruge, Jelašnička klisura and some others) with very small areas (less than $2.64 \mathrm{~km}^{2}$ ), where the measurement errors are significantly higher because of rounding numbers, the possible inaccuracies in borders of protected areas, as well as the Google Earth measuring capabilities. Besides, calculated data for two nature reserves (Bagremara and Selevenjske pustare) is respectively 3.5 and 2.75 times bigger than official areas of these objects. That is connected with zoning of the territories. Official data include only areas of their strict protected zone, but the available GIS layer with borders of these protected areas does not contain information about zones. Therefore, we were not able to count the level of ecological light pollution only for strict protected zones there, and we have done it for whole territories of these nature reserves. Nevertheless, such big differentiation, in this case, does not have a significant impact on the total result, because total areas of Bagremara and Selevenjske pustare Nature Reserves are relatively small. In light of the above stated, the differentiation between total calculated area and total official area of all strict protected areas of the Republic of Serbia is $0.60 \%$, for the Republic of Bulgaria, $0.86 \%$ 


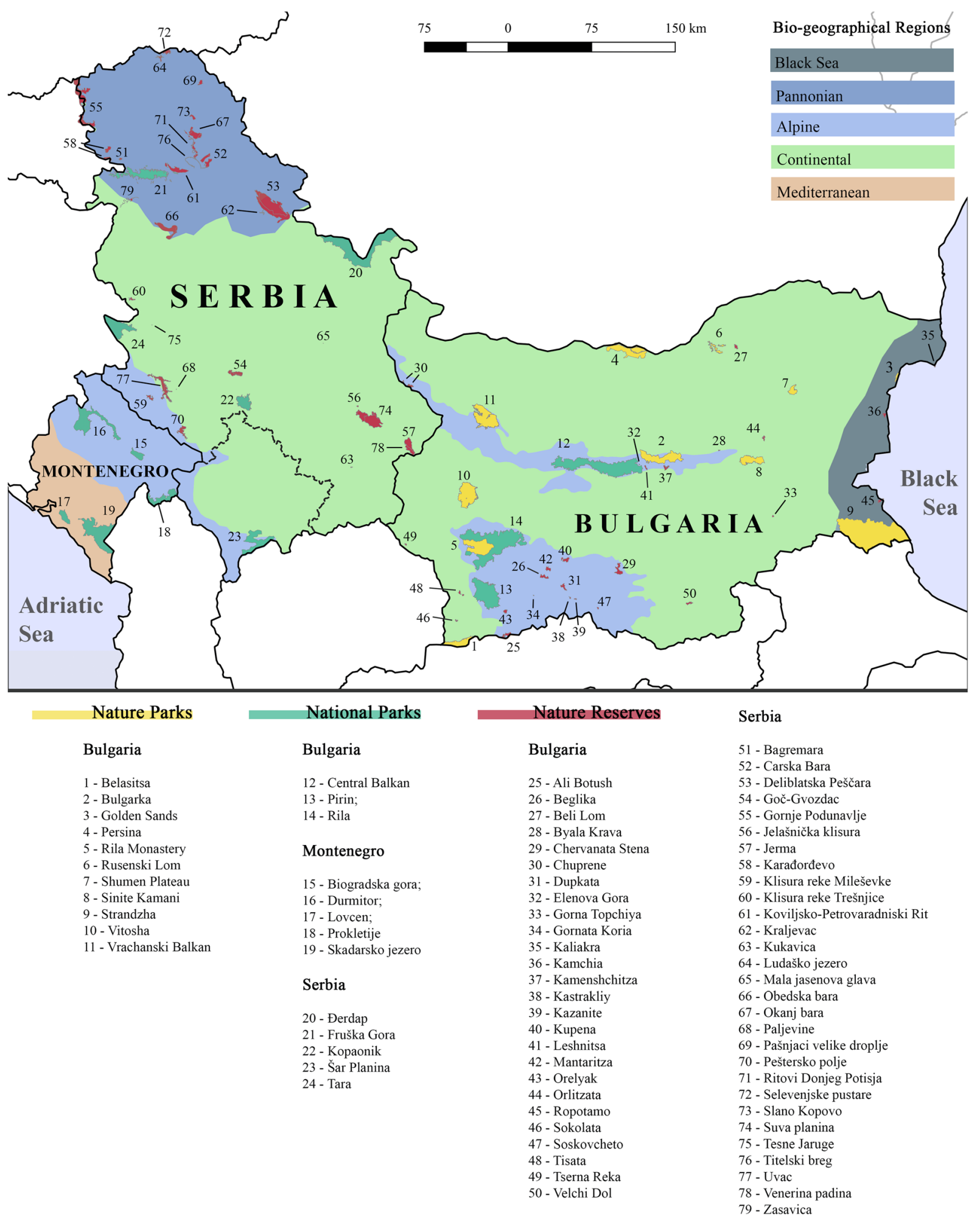

Fig. 1 Studied strict protected areas in Bulgaria, Montenegro, and Serbia 


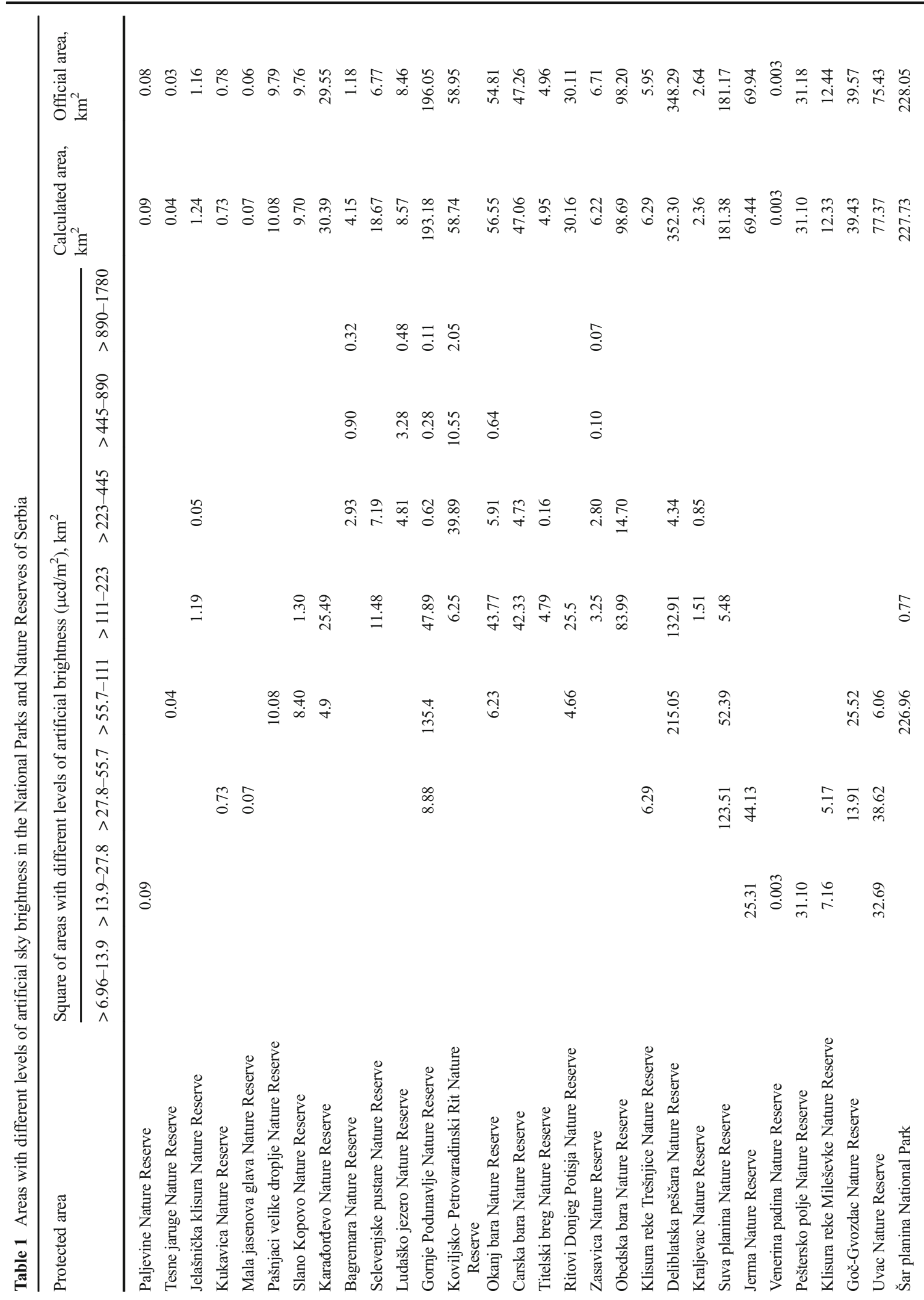




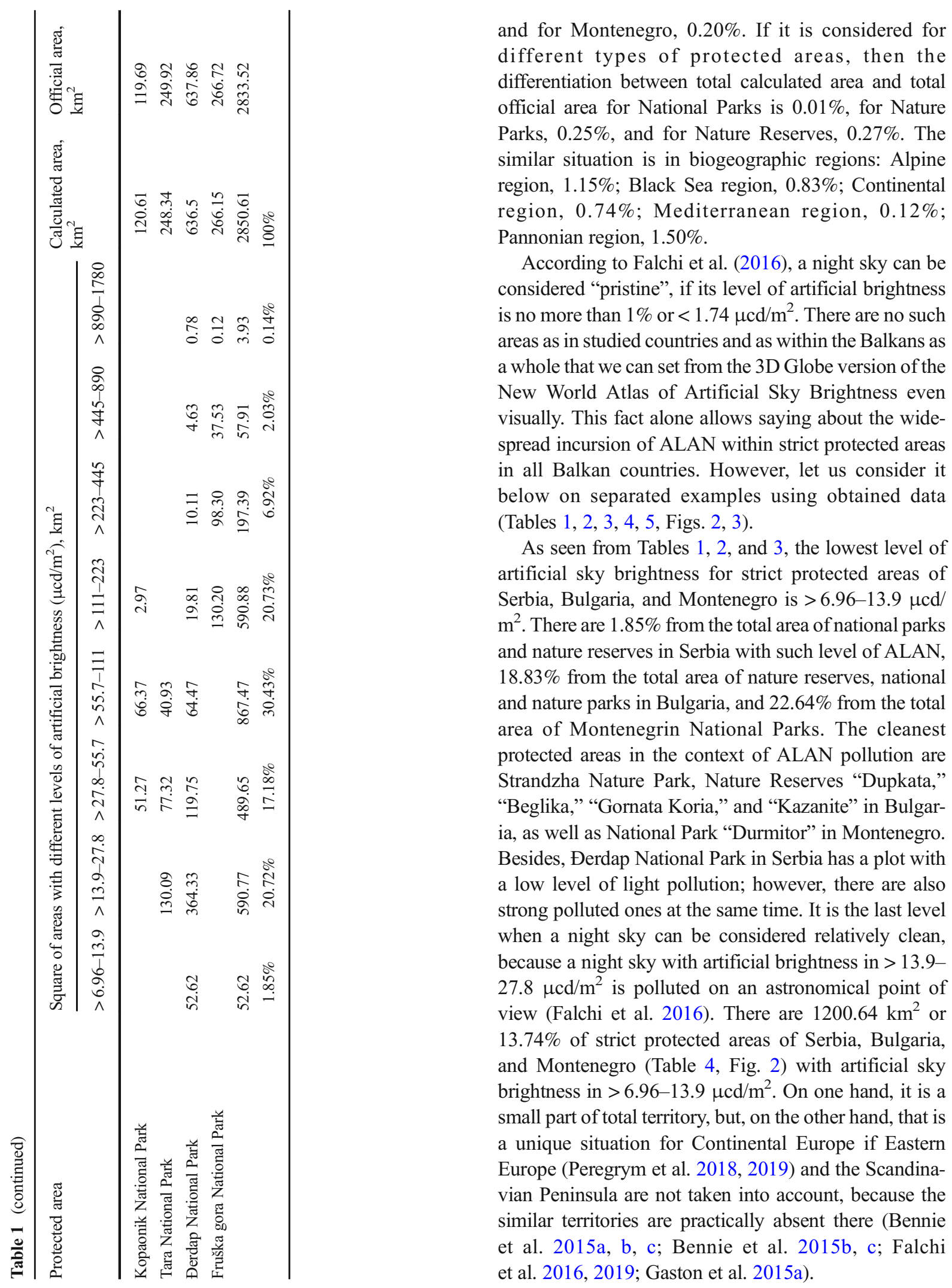




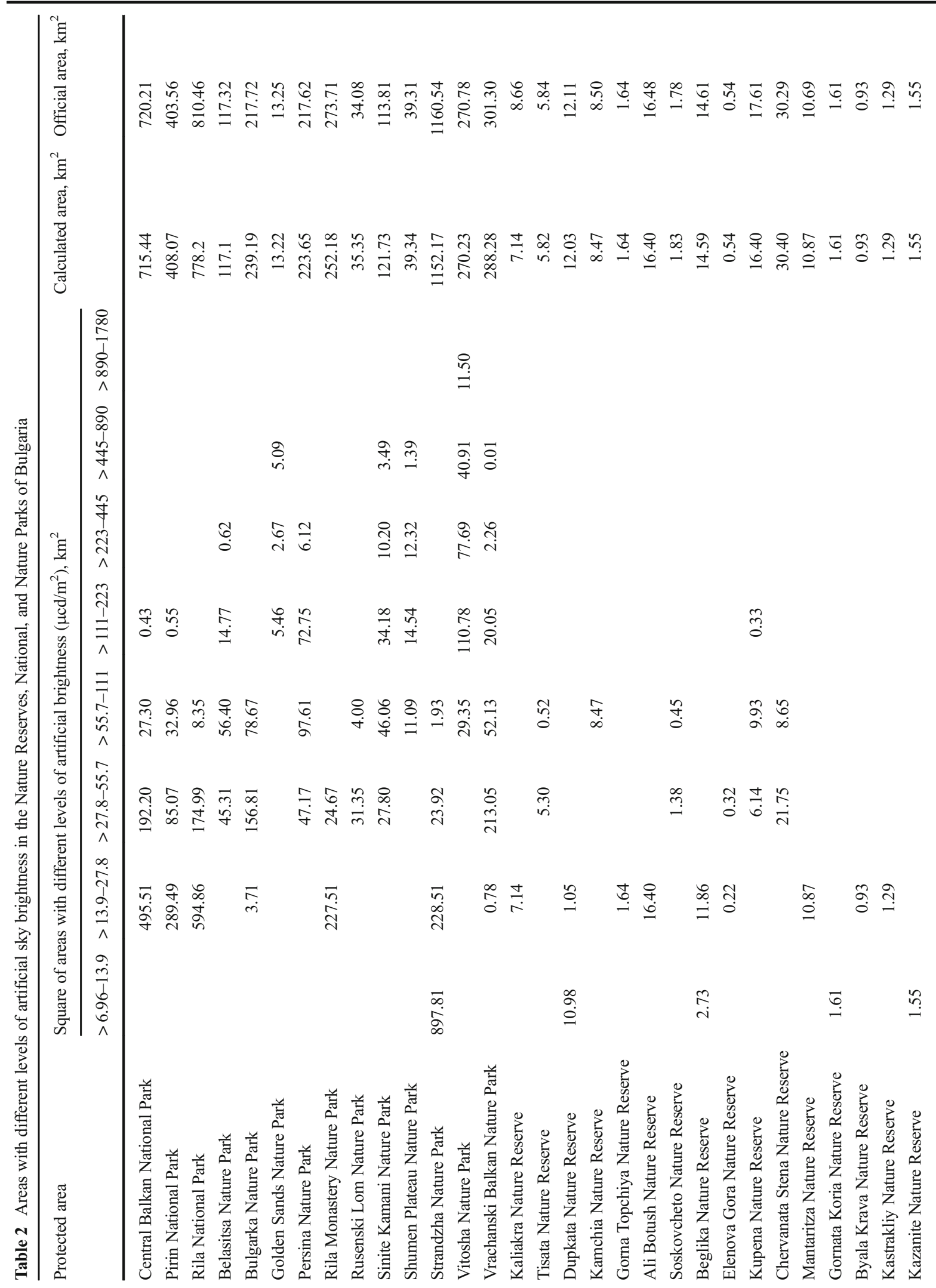




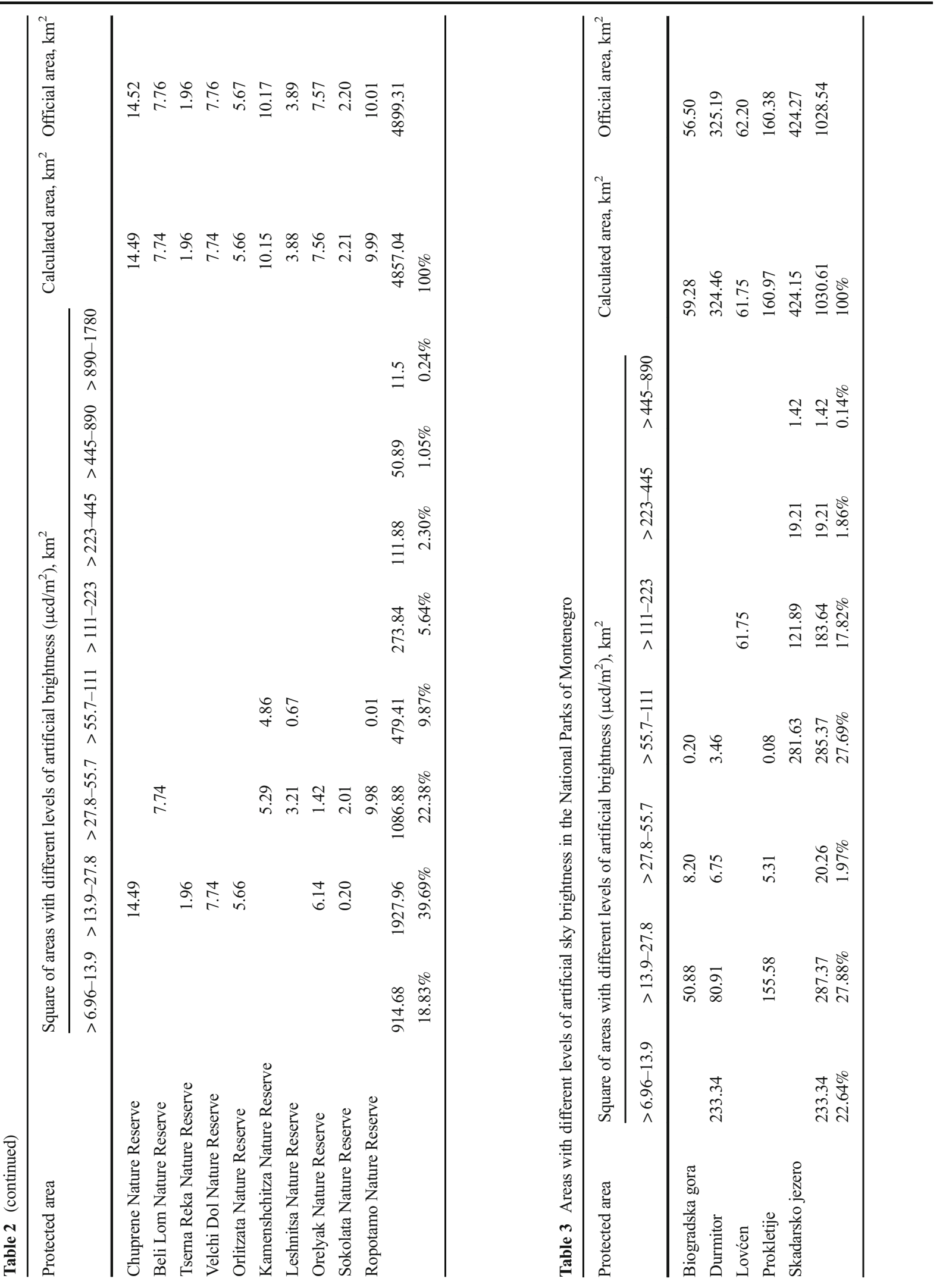




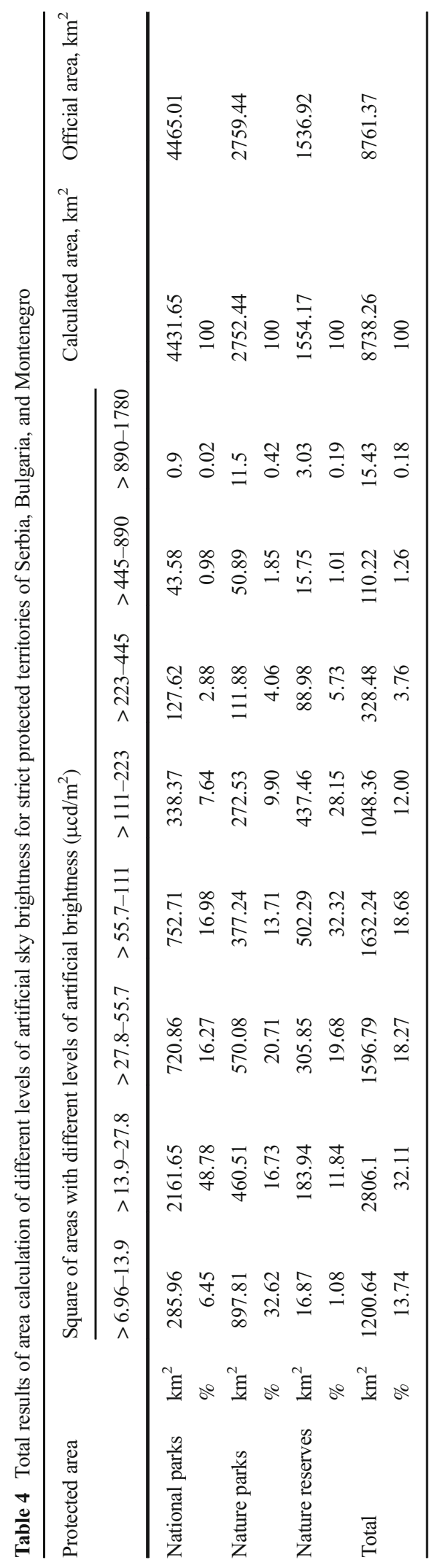

Nevertheless, strict protected areas of Serbia and Montenegro are very strongly polluted by ALAN generally (Fig. 2). So, there are $60.25 \%$ of strict protected areas of Serbia with artificial sky brightness more than $55.7 \mu \mathrm{cd} / \mathrm{m}^{2}$ and the maximum value of $1780 \mu \mathrm{cd} / \mathrm{m}^{2}$. It is $47.51 \%$ for Montenegro, but with the maximum value of $890 \mu \mathrm{cd} / \mathrm{m}^{2}$. The current situation in Bulgaria is different. There are only $19.1 \%$ of Bulgarian strict protected areas with artificial sky brightness more than $55.7 \mu \mathrm{cd} / \mathrm{m}^{2}$ and the maximum value of $1780 \mu \mathrm{cd} / \mathrm{m}^{2}$. Moreover, though there is almost $40 \%$ which are polluted on an astronomical point of view, potentially these can be cleared using a right policy in combating among ecological light pollution (Dick 2014, 2018; Hölker et al. 2010a).

Considering a potential "cleaning up" in strict protected areas from ALAN separately except Bulgarian National Parks, Rila Monestry Nature Park, and some Nature Reserves, the most perspective territories are National Parks "Prokletije" and "Biogradska gora" in Montenegro, as well as Tara National Park in Serbia. That is because they are located far enough from big settlements with developed infrastructure. Unfortunately, at present, it is complicated to wait for significant success in decreasing of ecological light pollution in National Parks like "Lovćen" and "Skadarsko jezero" because they are surrounded by cities and villages oriented to touristic business with active night life.

The result of data analysis from Table 4 shows that as a percentage the most ALAN polluted one are Nature Reserves among different types of strict protected areas of Serbia, Bulgaria, and Montenegro. There are 67.4\% of them with artificial sky brightness more than $55.7 \mu \mathrm{cd} / \mathrm{m}^{2}$ and the maximum value to $1780 \mu \mathrm{cd} / \mathrm{m}^{2}$. At the same time, it is $28.5 \%$ and $29.94 \%$ for national and nature parks, respectively. However, based on areas, the most polluted territories are national parks because there are $1268.18 \mathrm{~km}^{2}$ of their total area with artificial sky brightness more than $55.7 \mu \mathrm{cd} / \mathrm{m}^{2}$ and the maximum value to $1780 \mu \mathrm{cd} / \mathrm{m}^{2}$. This indicator is not significantly lower for nature reserves and nature parks$1047.51 \mathrm{~km}^{2}$ and $824.04 \mathrm{~km}^{2}$, respectively.

As seen from Table 5 and Fig. 3, the representation of Serbian, Bulgarian, and Montenegrin strict protected areas in biogeographic regions is different; therefore, it is not correct to compare them. However, it is clear that the most polluted strict protected areas by ALAN are located in the Mediterranean and Pannonian regions. Here is the lowest level in $>27.8-55.7 \mu \mathrm{cd} / \mathrm{m}^{2}$ for 


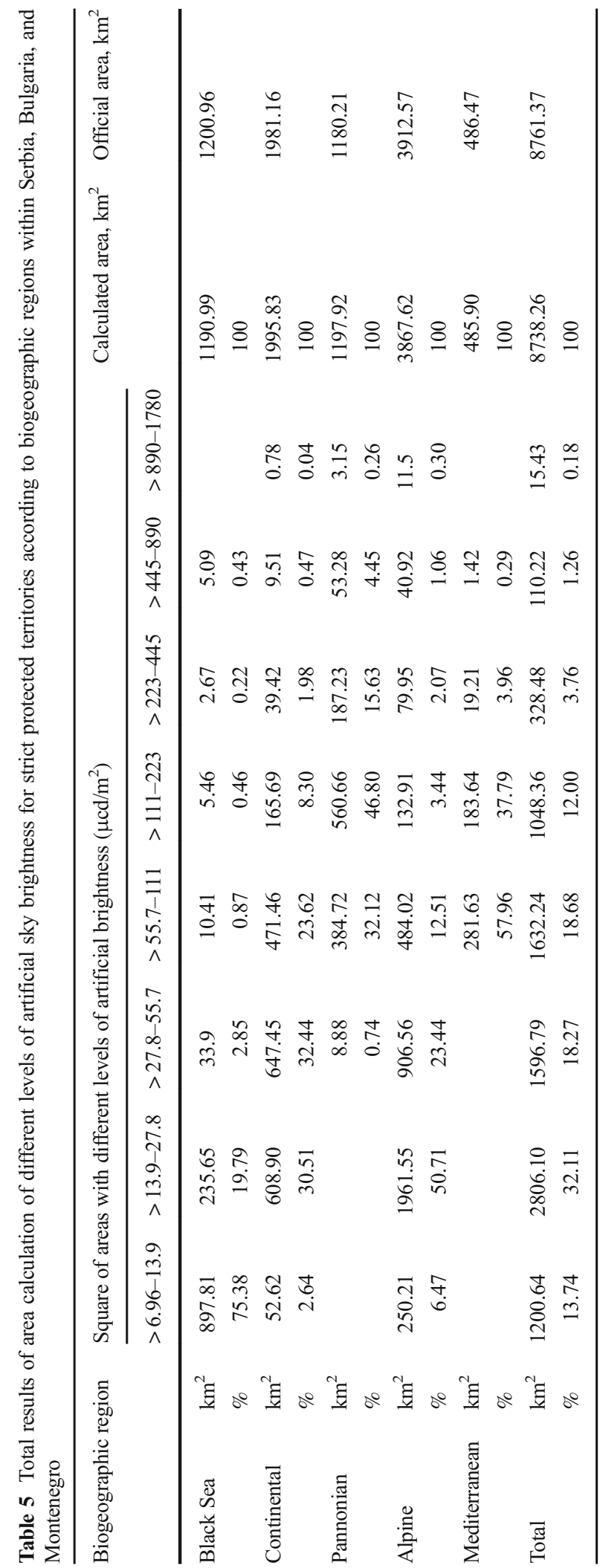




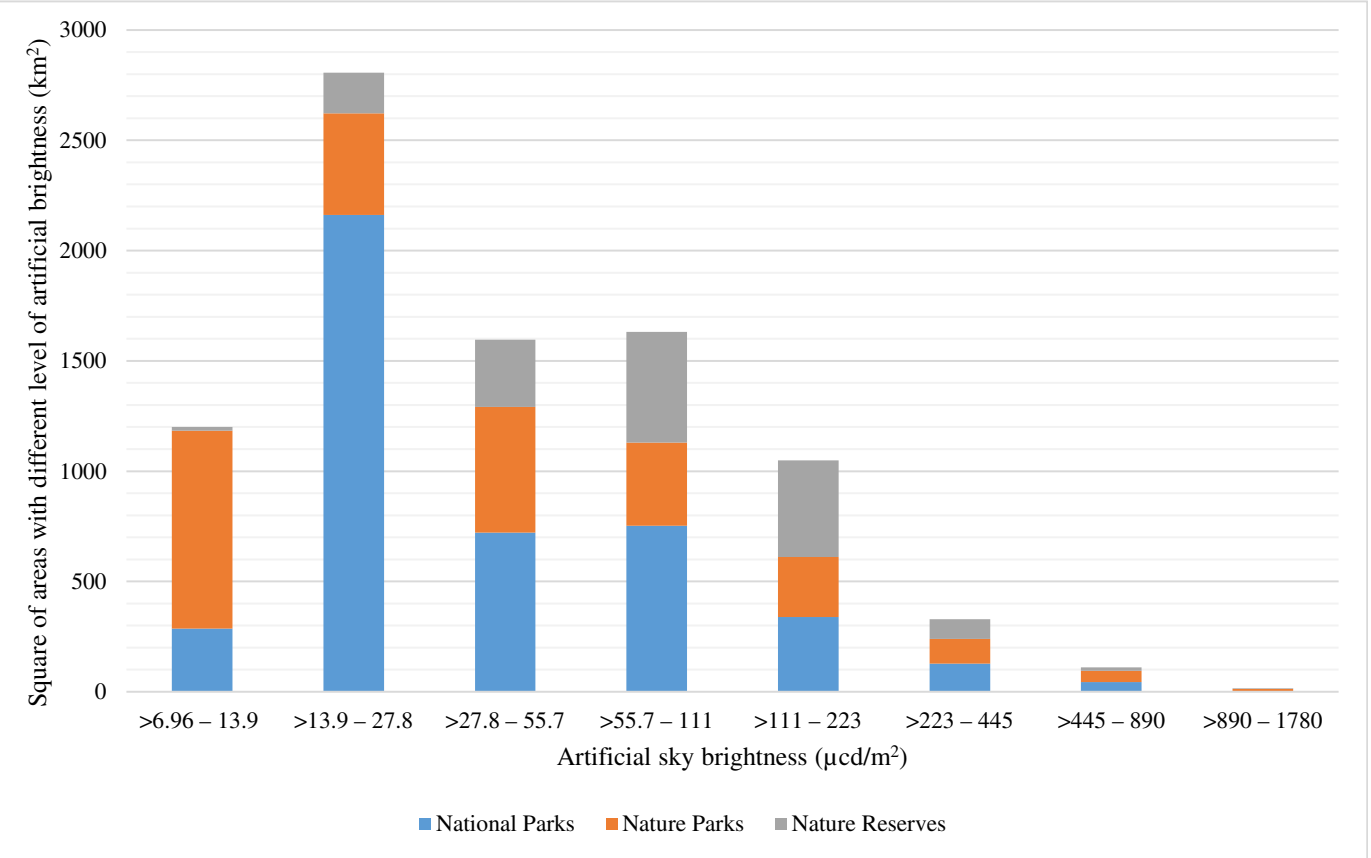

Fig. 2 Distribution of strict protected area types in respect to different levels of artificial sky brightness in Serbia, Bulgaria, and Montenegro

Pannonian region and in $>55.7-111 \mu \mathrm{cd} / \mathrm{m}^{2}$ for Mediterranean one. It is easy to explain because all seashore regions are strongly polluted by ALAN due to their attraction for tourists and transport infrastructure (Bennie et al. 2015c). Pannonian region within Serbia has a large number of population as well as some industry districts which provide the high level of ecological light pollution there. It was logical to expect the similar data for Black Sea region and the Mediterranean region which are quite popular among tourists. However, within Strandzha Nature Park, which is the biggest strict protected area and the cleanest one from ALAN in the region, there is the lowest level of ecological light pollution among all biogeographic regions represented in studied countries of the Balkans. It is a very positive moment because Strandzha is a unique place which considered to be a refugia of thermophilic plant species in the last glacial time (Patronov 2005). Also a relatively low level of ecological light pollution is in Alpine region that is connected with poorly developed infrastructure in high mountains. Nevertheless, there is $50.71 \%$ of strict protected areas polluted by ALAN on an astronomical point of view, and $42.82 \%$ has higher level of this pollution. The current situation is significantly worse in Continental region. Here is only $2.64 \%$ of strict protected areas which are relatively clean, with artificial brightness in range $>6.96-13.9 \mu \mathrm{cd} / \mathrm{m}^{2}$. Though there is a big potential for decreasing the level of ecological light pollution in this region, since $30.51 \%$ or $608.90 \mathrm{~km}^{2}$ has artificial brightness in range $>13.9$ $27.8 \mu \mathrm{cd} / \mathrm{m}^{2}$.

\section{Conclusions}

Thus, there is no doubt that ALAN significantly influences biota and its habitats in the Balkans, including strict protected areas. It is a new threat for nature conservation not just in Northern Serbia as mentioned earlier (Bjelajac and Đerčan 2019), but in the whole region. At least, this is confirmed by our results of the investigation for Serbia, Bulgaria, and Montenegro. The current research shows only a static situation for strict protected areas of Balkan countries because the New World Atlas of Artificial Sky Brightness (Falchi et al. 2016) does not allow making any dynamical estimation. However, taking into account the pace of ecological light pollution in the world increasing by a degree of $\sim 2 \%$ per year (Kyba et al. 2017), and the uniqueness of the Balkan Peninsula, first of all, it is very important to save dark skies in this region wherever possible, as well as to start combating for decreasing of ecological light 


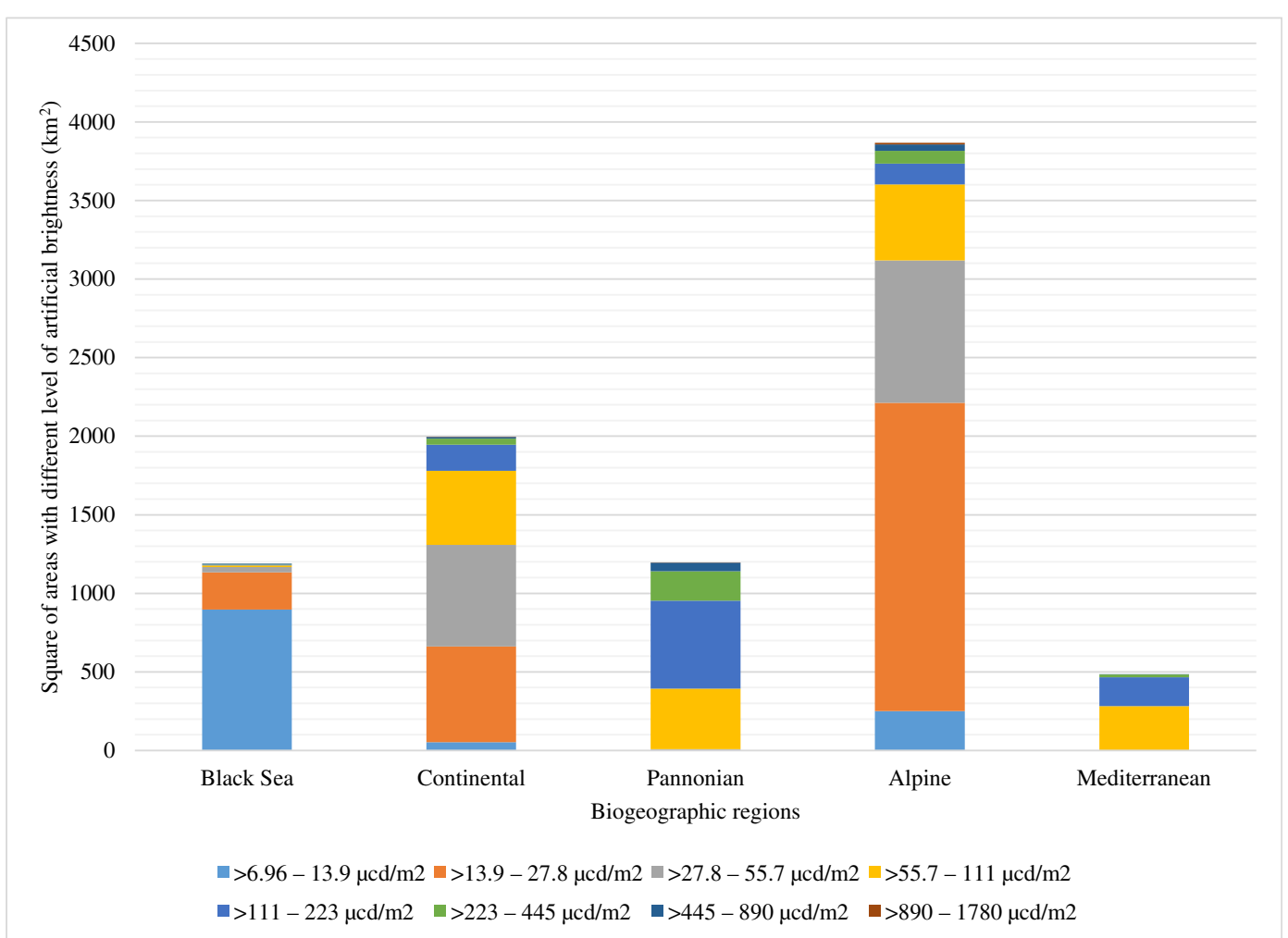

Fig. 3 Distribution of territories with different levels of artificial sky brightness in respect to biogeographical regions within Serbian, Bulgarian, and Montenegrin strict protected areas

pollution level where it is more perspective. Such activity has to be carried out within strict protected areas firstly, and has to be directed to both practical and educational aims. More difficult goal is to expand dark territories around these strict protected areas. Certainly this will be very hard to realize because of fast infrastructure development in these countries which is apparently often accompanied by increasing area of polluted territories, as well as the level of light pollution. However, the ideal aim is to build a regional network of dark areas which will join territories without light pollution or with its minimal level. It is needed for removal of any biogeographical barriers which appeared due to development of settlement light systems, since they influence on gene drift in populations significantly (Hopkins et al. 2018).

We think that changes in approaches to street light and lighting of buildings within protected areas and their surroundings, according to accepted recommendations (Dick 2014, 2018; Kolláth et al. 2016), have to be among the first practical steps. The next stage is creation of special buffer zones around strict protected areas for decreasing the ALAN impact from light sources of settlements and their infrastructure as well as starting taking into account ALAN effects during development of conservation management plans for protected areas and creation of new ones.

However, these actions must be simultaneous with designing and implementation of educational strategies, because nowadays even scientific popular information about the ALAN problem are limited. Also, it is very important to show to local communities the benefits from saving the dark sky and its impact on well-being, and as a result, conservation activities should be more effective. It is possible to do it by international collaboration, as an example in the framework of the International Dark Sky Places conservation program (http://darksky.org/idsp/) which has been initiated by the International Dark-Sky Association since 2001 (Barentine 2016). Fulfilling the requirements for 
International Dark Sky Places should provide benefits for both biodiversity conservation and tourism within protected areas. Such a positive experience has been documented in many countries, for example, in adjacent Hungary (Gyarmathy and Kolláth 2017).

Finally, continuous gathering of scientific facts about mechanisms of ALAN influence on biodiversity and protected areas is very important. Balkan countries could be a profitable place for it because of their unique biodiversity and habitat richness on a relatively small area.

Acknowledgments The authors are very grateful to a team of researchers led by Fabio Falchi who provided the kmz layer "The New World Atlas of Artificial Sky Brightness" prepared as a result of their project (https://cires.colorado.edu/Artificial-light), as well as special thanks to Slobodan Stijepović (Associate for forest protection at National parks of Montenegro) for the help about borders of Montenegrin National Parks.

Funding Information Open access funding provided by Eszterhazy Karoly University (EKE). The research has been carried out within the framework of the project EFOP-3.6.2-16-201700014 "Development of an international research environment in the field of light pollution testing," and grant no. 173030 of the Ministry of Education, Science and Technological development of the Republic of Serbia "Plant biodiversity of Serbia and the Balkans - assesment, sustainable use and protection."

Open Access This article is licensed under a Creative Commons Attribution 4.0 International License, which permits use, sharing, adaptation, distribution and reproduction in any medium or format, as long as you give appropriate credit to the original author(s) and the source, provide a link to the Creative Commons licence, and indicate if changes were made. The images or other third party material in this article are included in the article's Creative Commons licence, unless indicated otherwise in a credit line to the material. If material is not included in the article's Creative Commons licence and your intended use is not permitted by statutory regulation or exceeds the permitted use, you will need to obtain permission directly from the copyright holder. To view a copy of this licence, visit http://creativecommons.org/licenses/by/4.0/.

\section{References}

Angelova, A., Apostolova, I., Assyov, B., Bancheva, S., Venkova, D., Vladimirov, V., et al. (2012). In D. Peev, A. Petrova, I. Apostolova, \& B. Assyov (Eds.), Important plant areas in Bulgaria. Pensoft: Sofia.

Barentine, J. (2016). Going for the Gold : Quantifying and ranking visual night sky quality in International Dark Sky Places. International Journal of Sustainable Lighting, 18(2), 9-15. https://doi.org/10.26607/ijsl.v18i0.16.

Bennie, J., Davies, T. W., Cruse, D., Inger, R., \& Gaston, K. J. (2015a). Cascading effects of artificial light at night:
Resource-mediated control of herbivores in a grassland ecosystem. Philosophical Transactions of the Royal Society, B: Biological Sciences, 370(1667), 20140131. https://doi. org/10.1098/rstb.2014.0131.

Bennie, J., Davies, T. W., Duffy, J. P., Inger, R., \& Gaston, K. J. (2015b). Contrasting trends in light pollution across Europe based on satellite observed night time lights. Scientific Reports, 4, 3789. https://doi.org/10.1038/srep03789.

Bennie, J., Duffy, J. P., Davies, T. W., Correa-Cano, M. E., \& Gaston, K. J. (2015c). Global trends in exposure to light pollution in natural terrestrial ecosystems. Remote Sensing, 7, 2715-2730. https://doi.org/10.3390/rs70302715.

Bennie, J., Davies, T. W., Cruse, D., \& Gaston, K. J. (2016). Ecological effects of artificial light at night on wild plants. Journal of Ecology, 104(3), 611-620. https://doi.org/10.1111 /1365-2745.12551.

Bjelajac, D., \& Đerčan, B. (2019). Artificial light at night as an unrecognized threat to protected areas of Autonomous Province of Vojvodina (North Serbia). Zbornik radova Departmana za geografiju, turizam $i$ hotelijerstvo, 48(1), 46-56. https://doi.org/10.5937/ZbDght1901046B.

Boyce, P. R. (2019). The benefits of light at night. Building and Environment, 151, 356-367. https://doi.org/10.1016/j. buildenv.2019.01.020.

Brusin, A. (2018). Overview of protected areas in the Republic of Serbia. Nature Conservation, 68(1-2), 13-40. http://www. zzps.rs/novo/kontent/casopisi/025/casopis.pdf. Accessed 21 October 2019

Cinzano, P., Falchi, F., \& Elvidge, C. D. (2001). The first World Atlas of the artificial night sky brightness. Monthly Notices of the Royal Astronomical Society, 328(3), 689-707. https://doi. org/10.1046/j.1365-8711.2001.04882.x.

Convention on the Conservation of European Wildlife and Natural Habitats. (2008). Development of the Emerald Sites Network in South-East Europe under the CARDS programme of the European Environment Agency. Strasbourg. https://rm.coe. int/CoERMPublic Common Search Services/ DisplayDCTMContent?documentId=09000016807463 cd. Accessed 21 October 2019.

Dick, R. (2014). Applied scotobiology in luminaire design. Lighting Research \& Technology, 46(1), 50-66. https://doi. org/10.1177/1477153513505758.

Dick, R. (2018). Guidelines for outdoor lighting (low-impact lighting) for RASC dark-sky protection programs (DarkSky Preserves, Nocturnal Preserves, Urban Star Parks). https://www.darksky.org/wp-content/uploads/bsk-pdfmanager/RASC-GOL_2018_51.pdf. Accessed 9 January 2019.

Dominoni, D. M., Borniger, J. C., \& Nelson, R. J. (2016). Light at night, clocks and health: From humans to wild organisms. Biology Letters, 12(2), 20160015. https://doi.org/10.1098 /rsbl.2016.0015.

European Commission. (2019). The Natura 2000 Biogeographical Regions. https://ec.europa.eu/environment/nature/natura2000 /biogeog_regions/. Accessed 2 October 2019.

European Environment Agency. (2012). Biogeographic regions of Europe, with overlay of mountain area as defined for the present study. https://www.eea.europa.eu/data-andmaps/figures/biogeographic-regions-of-europe-with. Accessed 2 October 2019. 
Falchi, F. (2018). Light pollution. In Urban pollution (pp. 147159). Chichester: Wiley. https://doi.org/10.1002 /9781119260493.ch11.

Falchi, F., Cinzano, P., Duriscoe, D., Kyba, C. C. M., Elvidge, C. D., Baugh, K., et al. (2016). The new world atlas of artificial night sky brightness. Science Advances, 2(6), e1600377. https://doi.org/10.1126/sciadv.1600377.

Falchi, F., Furgoni, R., Gallaway, T. A., Rybnikova, N. A., Portnov, B. A., Baugh, K., et al. (2019). Light pollution in USA and Europe: The good, the bad and the ugly. Journal of Environmental Management, 248, 109227. https://doi. org/10.1016/j.jenvman.2019.06.128.

Gaston, K. J., \& Bennie, J. (2014). Demographic effects of artificial nighttime lighting on animal populations. Environmental Reviews, 22(4), 323-330. https://doi. org/10.1139/er-2014-0005.

Gaston, K. J., Duffy, J. P., \& Bennie, J. (2015a). Quantifying the erosion of natural darkness in the global protected area system. Conservation Biology, 29(4), 1132-1141. https://doi. org/10.1111/cobi.12462.

Gaston, K. J., Gaston, S., Bennie, J., \& Hopkins, J. (2015b). Benefits and costs of artificial nighttime lighting of the environment. Environmental Reviews, 23(1), 14-23. https://doi. org/10.1139/er-2014-0041.

Griffiths, H. I., \& Kryštufek, B. (2004). In J. M. Reed (Ed.), Balkan biodiversity: Pattern and process in the European hotspot. Dordrecht: Springer Netherlands. https://doi. org/10.1007/978-1-4020-2854-0.

Group of Experts for the setting up of the Emerald Network of Areas of Special Conservation Interest. (2003). Emerald Network Pilot Project in "the former Yugoslav Republic of Macedonia." Strasbourg. https://search.coe. $\mathrm{i} \mathrm{n} \mathrm{t/} \mathrm{c} \mathrm{d} \mathrm{p} \mathrm{c} \mathrm{/} \mathrm{P} \mathrm{a} \mathrm{g} \mathrm{e} \mathrm{s} \mathrm{/} \mathrm{r} \mathrm{e} \mathrm{s} \mathrm{u} 1$ t_d e t a i $1 \mathrm{~s}$. aspx ?ObjectId $=09000016809288 \mathrm{a} 8$. Accessed 21 October 2019.

Group of Experts for the setting up of the Emerald Network of Areas of Special Conservation Interest. (2006). Emerald Network Pilot Project in Bosnia and Herzegovina. Strasbourg. https://search.coe.int/bern-convention/Pages/result_details. aspx? ObjectId $=090000168074660 \mathrm{~b}$

Grubisic, M., van Grunsven, R. H. A., Kyba, C. C. M., Manfrin, A., \& Hölker, F. (2018). Insect declines and agroecosystems: Does light pollution matter? Annals of Applied Biology, 173(2), 180-189. https://doi.org/10.1111/aab.12440.

Guetté, A., Godet, L., Juigner, M., \& Robin, M. (2018). Worldwide increase in artificial light at night around protected areas and within biodiversity hotspots. Biological Conservation, 223, 97-103. https://doi.org/10.1016/j. biocon.2018.04.018.

Gussev, C., \& Tzonev, R. (2015). European Ecological Network NATURA 2000 in Bulgaria. In V. Biserkov, C. Gussev, V. Popov, G. Hibaum, V. Roussakova, I. Pandurski, et al. (Eds.), Red data book of the Republic of Bulgaria. Volume 3. Natural habitats (pp. 34-41). Sofia: IBEI - BAS \& MOEW.

Gyarmathy, I., \& Kolláth, Z. (2017). Hortobágy National Park-an island of undisturbed nighttime environment. International Journal of Sustainable Lighting, 19(1), 1-9. https://doi. org/10.26607/ijsl.v19i1.60.

Hallmann, C. A., Sorg, M., Jongejans, E., Siepel, H., Hofland, N., Schwan, H., et al. (2017). More than 75 percent decline over 27 years in total flying insect biomass in protected areas.
PLoS One, 12(10), e0185809. https://doi.org/10.1371 /journal.pone.0185809.

Hölker, F., Moss, T., Griefahn, B., Kloas, W., Voigt, C. C., Henckel, D., et al. (2010a). The dark side of light: A transdisciplinary research agenda for light pollution policy. Ecology and Society, 15(4), art13. https://doi.org/10.5751 /ES-03685-150413.

Hölker, F., Wolter, C., Perkin, E. K., \& Tockner, K. (2010b). Light pollution as a biodiversity threat. Trends in Ecology \& Evolution, 25(12), 681-682. https://doi.org/10.1016/j. tree.2010.09.007.

Hopkins, G. R., Gaston, K. J., Visser, M. E., Elgar, M. A., \& Jones, T. M. (2018). Artificial light at night as a driver of evolution across urban-rural landscapes. Frontiers in Ecology and the Environment, 16(8), 472-479. https://doi.org/10.1002 /fee. 1828 .

Jiang, W., He, G., \& Ni, Y. (2017). Assessment of light pollution impact on protected areas in China. ISPRS - International Archives of the Photogrammetry, Remote Sensing and Spatial Information Sciences, XLII-2(W7), 1307-1312. https://doi.org/10.5194/isprs-archives-XLII-2-W7-13072017.

Kolláth, Z., Dömény, A., Kolláth, K., \& Nagy, B. (2016). Qualifying lighting remodelling in a Hungarian city based on light pollution effects. Journal of Quantitative Spectroscopy and Radiative Transfer, 181, 46-51. https://doi.org/10.1016/j.jqsrt.2016.02.025.

Kulakowski, D., Seidl, R., Holeksa, J., Kuuluvainen, T., Nagel, T. A., Panayotov, M., et al. (2017). A walk on the wild side: Disturbance dynamics and the conservation and management of European mountain forest ecosystems. Forest Ecology and Management, 388, 120-131. https://doi.org/10.1016/j. foreco.2016.07.037.

Kyba, C. C. M., Kuester, T., Sánchez de Miguel, A., Baugh, K., Jechow, A., Hölker, F., et al. (2017). Artificially lit surface of earth at night increasing in radiance and extent. Science Advances, 3(11), e1701528. https://doi.org/10.1126 /sciadv.1701528.

Leather, S. R. (2018). “Ecological Armageddon"-more evidence for the drastic decline in insect numbers. Annals of Applied Biology, 172(1), 1-3. https://doi.org/10.1111/aab.12410.

Longcore, T., \& Rich, C. (2004). Ecological light pollution. Frontiers in Ecology and the Environment, 2(4), 191-198. https://doi.org/10.1890/1540-9295(2004)002[0191:ELP]2.0. $\mathrm{CO} ; 2$.

Longman, J., Veres, D., Finsinger, W., \& Ersek, V. (2018). Exceptionally high levels of lead pollution in the Balkans from the Early Bronze Age to the Industrial Revolution. Proceedings of the National Academy of Sciences, 115(25), E5661-E5668. https://doi.org/10.1073/pnas.1721546115.

Macgregor, C. J., Pocock, M. J. O., Fox, R., \& Evans, D. M. (2015). Pollination by nocturnal Lepidoptera, and the effects of light pollution: A review. Ecological Entomology, 40(3), 187-198. https://doi.org/10.1111/een.12174.

Marinova, E., Tonkov, S., Bozilova, E., \& Vajsov, I. (2012). Holocene anthropogenic landscapes in the Balkans: The palaeobotanical evidence from southwestern Bulgaria. Vegetation History and Archaeobotany, 21(4-5), 413-427. https://doi.org/10.1007/s00334-011-0345-8.

Melovski, L., Velevski, M., Matevski, V., Avukatov, V., \& Sarov, A. (2012). Using important plant areas and important bird 
areas to identify key biodiversity areas in the Republic of Macedonia. Journal of Threatened Taxa, 04(08), 2766-2778. https://doi.org/10.11609/JoTT.o2997.2766-78.

Mittermeier, R. A., Myers, N., Goettsch Mittermeier, C., \& Robles Gil, P. (1999). Hotspots: Earth's biologically richest and most endangered terrestrial ecoregions. Mexico City: Agrupación Sierra Madre.

Mittermeier, R. A., Robles Gil, P., Hoffman, M., Pilgrim, J., Brooks, T., Goettsch Mittermeier, C., et al. (2005). Hotspots revisited: Earth's biologically richest and most endangered terrestrial ecoregions. Mexico City: Agrupacion Sierra Madre.

Myers, N., Mittermeier, R. A., Mittermeier, C. G., da Fonseca, G. A. B., \& Kent, J. (2000). Biodiversity hotspots for conservation priorities. Nature, 403(6772), 853-858. https://doi. org/10.1038/35002501.

Navara, K. J., \& Nelson, R. J. (2007). The dark side of light at night: Physiological, epidemiological, and ecological consequences. Journal of Pineal Research, 43(3), 215-224. https://doi.org/10.1111/j.1600-079X.2007.00473.x.

Nikolić, T. (2009). Croatia. In E. A. Radford \& B. Odé (Eds.), Conserving important plant areas: Investing in the Green Gold of South East Europe (pp. 37-44). Salisbury: Plantlife International.

Patronov, D. (2005). Upward Strandja Mountains. Burgas: Libra Scorp.

Peregrym, M., Pénzesné Kónya, E., \& Vasyliuk, O. (2018). The impact of artificial light at night (ALAN) on the national nature parks, biosphere and nature reserves of the steppe zone and Crimean Mountains within Ukraine. Palearctic Grasslands, (39), 8-14. https://doi.org/10.21570/EDGG. PG.39.8-14.

Peregrym, M., Vasyliuk, O., \& Pénzesné Kónya, E. (2019). Artificial light at night as a new threat for nature conservation in Ukraine. Vestnik Zoologii, 53(6), 459-470. https://doi. org/10.2478/vzoo-2019-0041.

Petrova, A., \& Vladimirov, V. (2010). Balkan endemics in the Bulgarian flora. Phytologia Balcanica, 16(2), 293-311.

Petrović, D. (2009). Montenegro. In E. A. Radford \& B. Odé (Eds.), Conserving important plant areas: Investing in the Green Gold of South East Europe (pp. 55-62). Salisbury: Plantlife International.
Prokić, S. (2008). Introductory report on nature conservation in Serbia. Strasbourg. https://search.coe.int/bernc onvention/Pages/result_details. aspx? ObjectId=090000168074693a. Accessed 21 October 2019.

Puzovič, S. (Ed.). (2009). Important bird areas in Serbia. Beograd - Novi Sad.

Rich, C., \& Longcore, T. (Eds.). (2006). Ecological consequences of artificial night lighting. Washington, DC: Island Press.

Stevanović, V., \& Šinžar-Sekulić, J. (2009). Serbia. In E. A. Radford \& B. Odé (Eds.), Conserving important plant areas: Investing in the Green Gold of South East Europe (pp. 6368). Salisbury: Plantlife International.

The European Environment Agency. (2011). Environmental trends and perspectives in the Western Balkans: Future production and consumption patterns. Copenhagen. https://doi. org/10.2800/72655.

The Ministry of Environment and Water of Bulgaria. (2014). National Prioritised Action Framework (NPAF) for Natura 2000 Bulgaria for the EU Multiannual Financing Period 2014-2020. https://www.moew.government.bg/bg/nationalprioritised-action-framework-npaf-for-natura-2000bulgaria/\#attached-files. Accessed 16 October 2019.

Tomović, G., Niketić, M., Lakušić, D., Randelović, V., \& Stevanović, V. (2014). Balkan endemic plants in Central Serbia and Kosovo regions: Distribution patterns, ecological characteristics, and centres of diversity. Botanical Journal of the Linnean Society. https://doi.org/10.1111/boj.12197.

Velevski, M., Hallmann, B., Grubač, B., Lisičanec, T., Stoynov, E., Lisičanec, E., et al. (2010). Important bird areas in Macedonia: Sites of global and European importance. Acrocephalus, 31(147), 181-282. https://doi.org/10.2478 /v10100-010-0009-2.

Vuksanović, S., Tomović, G., Niketić, M., \& Stevanović, V. (2016). Balkan endemic vascular plants of MontenegroCritical inventory with chorological and life-form analyses. Willdenowia, 46(3), 387-397. https://doi.org/10.3372 /wi.46.46307.

Publisher's Note Springer Nature remains neutral with regard to jurisdictional claims in published maps and institutional affiliations. 